Uluslararası Sosyal Bilgilerde Yeni Yaklaşımlar Dergisi, 2021, 5(1), 135-151

International Journal of New Approaches in Social Studies, 2021, 5(1), 135-151

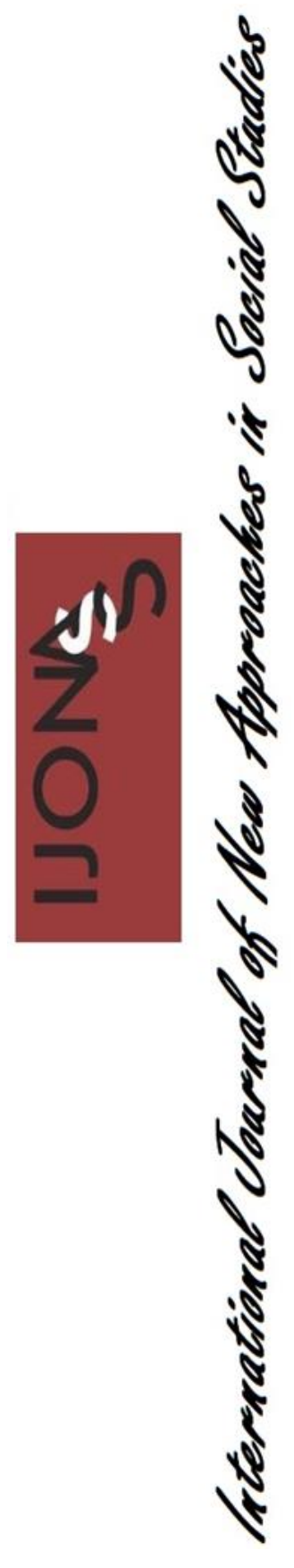

\title{
Öğretmen Adaylarının Millî Parklara Yönelik Algı ve Bilgi Düzeyleri: İlişskisel Bir Çalışma*
}

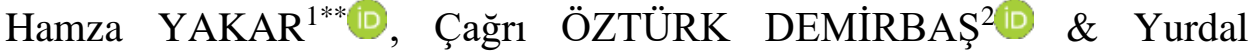 \\ DIKMENLi'
}

Gönderilme Tarihi: 25 Mart 2021

Kabul Tarihi: 24 Mayıs 2021

DOI: $10.38015 /$ sbyy. 903158

\begin{abstract}
$\ddot{O}_{z:}$
Bu araştırmanın amacı, öğretmen adaylarının millî parklara yönelik algı düzeyleri ile bilgi düzeyleri arasındaki ilişkiyi incelemektir. Bu amaç çerçevesinde araştırma, ilişkisel tarama modelinde gerçekleştirilmiştir. Araştırmanın katılımcılarını, 2016-2017 eğitim öğretim yılı bahar yarıyılında Kırşsehir Ahi Evran Üniversitesi Eğitim Fakültesi'nde öğrenim gören farklı sinıf düzeylerinde 711 ögrretmen adayı oluşturmaktadır. Araştırma kapsamında ilk olarak öğretmen adaylarının millî park bilgi düzeylerini ölçmeye yönelik çoktan seçmeli beş seçenekli Millî Park Başarı Testi (MPBT) hazırlanmıştır. Araștırmacılar tarafından son şekli verilen bașarı testi, çalıșma grubuna uygulanarak ögretmen adaylarının millî park bilgi düzeyleri belirlenmiştir. Araştırmanın ikinci aşamasında, ögretmen adaylarının millî park algılarının belirlenebilmesi için araştırmacılar tarafindan geliștirilen ve 31 madde ve 3 boyuttan oluşan Millî Park Algı Ölçeği (MPAÖ) kullanılmıștır. Araştırmacılar tarafindan geliştirilen algı ölçeği ve başarı testine verilen yanıtlara göre, öğretmen adaylarının millî park algl ve bilgi düzeyleri belirlenmiştir. Öğretmen adaylarının millî parklara yönelik algı düzeyleri ile bilgi düzeyleri arasında anlamlı bir ilişki olup olmadığını belirlemek için, basit korelasyon analizi yapılmıştır. Yapılan analizler sonucunda, ögretmen adaylarının genel millî park algılarının orta düzeyde olduğu tespit edilmiştir. Millî parklara ilişkin eğitimsel boyutta yüksek algıya sahip olan ögretmen adaylarının özyeterlilik ve seçimsel algl boyutlarında orta düzeyde alglya sahip olduklarl belirlenmiștir. Buna karșın, öğretmen adaylarının millî park bilgi düzeylerinin ise yetersiz olduğu ve millî parklara yönelik başarı düzeyleri ile algı düzeyleri arasında düşük düzeyde, pozitif yönlü ve anlamlı bir ilişki olduğu sonucuna ulaşılmıştır.
\end{abstract}

Anahtar Kelimeler: Millî park, millî park algısı, öğretmen adayı.

\begin{abstract}
:
The aim of this study is to examine the relationship between teacher candidates' perception and their knowledge levels towards national parks. For this purpose, the research was carried out in relational scanning model. The participants of the study consist of 711 teacher candidates from different grade levels studying at Kirşehir Ahi Evran University Faculty of Education in the spring semester of the 2016-2017 academic year. Within the scope of the research, firstly, the National Park Achievement Test (NPAT) with five options was prepared to measure the national park knowledge
\end{abstract}

\footnotetext{
${ }^{1}$ Kırşehir Ahi Evran Üniversitesi, Türkiye, ORCID ID: 0000-0002-9334-3525

${ }^{2}$ Kırșehir Ahi Evran Üniversitesi, Türkiye, ORCID ID: 0000-0001-8719-4167

${ }^{3}$ Kırşehir Ahi Evran Üniversitesi, Türkiye, ORCID ID: 0000-0003-3738-3095

* Bu araştırma, Kırşehir Ahi Evran Üniversitesi Bilimsel Araştırma Projeleri Koordinasyon Birimi tarafından (Proje No. EGT. A4. 17. 003) desteklenmiştir. Araştırmanın bir kısmı III. Uluslararası Sosyal Bilimler Araştırmaları Kongresi'nde (Makedonya, 05-08 Eylül 2018) sözlü bildiri olarak sunulmuştur.

${ }^{* * *}$ SorumluYazar (Corresponding Author): hmzyakar@gmail.com
} 
level of teacher candidates. The achievement test, which was finalized by the researchers, was applied to the study group and the national park knowledge levels of the teacher candidates were determined. In the second stage of the study, the National Park Perception Scale (NPPS), which was developed by the researchers and consists of 31 items and 3 dimensions, was used to determine the national park perceptions of the teacher candidates. According to the answers given to the perception scale and achievement test developed by the researchers, the national park perception and knowledge levels of the teacher candidates were determined. A simple correlation analysis was conducted to determine whether there is a significant relationship between teacher candidates' perception levels towards national parks and their level of knowledge. As a result of the analysis, it was determined that the general national park perception of the teacher candidates was at a medium level. It was determined that teacher candidates who have a high perception of national parks in the educational dimension have a medium level of self-efficacy and selective perception. On the other hand, it was concluded that the national park knowledge levels of the teacher candidates were insufficient and there was a low level, positive and significant relationship between their achievement and perception levels towards national parks.

Keywords: National park, national park perception, teacher candidate.

\section{GİRIȘ}

Dünyada doğayı korumaya yönelik çalışmalar, çok eski zamanlara kadar gitmektedir. Buna rağmen günümüzde kullanılan bazı kavram ve uygulamaların kökeni, 19. yüzyıl başlarına dayanmaktadır. Günümüzde, birçok ülkede farklı şekillerde belirlenmiş çok sayıda doğa koruma alanı bulunmaktadır. Buna bağlı olarak doğa koruma alanların sayısı ve büyüklüğü giderek artış göstermektedir (Kurdoğlu, 2007). Doğa koruma alanları içerisinde en çok karşılaşılan alanlardan birisi de millî parklardır. Millî parklar, barındırdıkları kaynaklar itibariyle ciddi bir eğitim imkânı sağlamakta ve birer açık hava laboratuvarı gibi nitelendirilmektedir (Yaşar, 2000). Ülkemizde korunan alanlar olan millî parklar; insan etkisine uğramamış, tarihi, estetik ve doğal ortam açısından bilimsel önemi olan, bilimsel çalışmalar yapılan, sınırları belli özel alanlardır. Başka bir ifade ile millı̂ park; bilimsel ve estetik bakımdan, ulusal ve uluslararası alanda ender bulunan tabii ve kültürel kaynak değeri ile koruma, dinlenme ve turizm alanlarına sahip tabiat parçalarıdır (Ozaner, 2002). Millî park bilgisi, algısı ve eğitimi ile millî parkların ve yakın çevresinin sunduğu doğal, tarihi ve kültürel değerleri bireylere tanıtmak, buna ek olarak bireylerin park niteliklerini gözlemleme, buraların denge, renk, biçim ve estetiğindeki çeşitliliği ve özgünlüğü anlayabilme becerisi kazandırmak hedeflenmektedir. Bunlara bağlı olarak, nihayetinde bireylerin doğa koruma alanlarına karşı sorumluluk kazanmaları beklenmektedir (Ozaner, 2003).

Millî park alanları, 1983 yılında kabul edilen Millî Parklar Kanunu'nda “bilimsel ve estetik bakımından millî ve milletlerarası ender bulunan doğal ve kültürel kaynak değerleri ile koruma, dinlenme ve turizm alanlarına sahip tabiat parçalarıdır" şeklinde tanımlanmaktadır. Millî parklar gibi doğa koruma alanları, bir laboratuvar olarak kabul edilerek eğitim amaçlı değerlendirilmektedir (Atik \& Toksöz, 2005). Millî parkların amacı, doğada nasıl davranılacağını, doğa eğitimi ve etiğini kazandırarak topluma doğayı tanıtmak, çevre ve doğa koruma bilincinin oluşmasını sağlamaktır (Şahbaz \& Altınay, 2015). 2021 yılı itibari ile Türkiye'de 45 millî park (MP) bulunmaktadır. T.C. Tarım ve Orman Bakanlığg Doğa Koruma ve Millî Parklar Genel Müdürlüğü tarafından güncel olarak yayınlanan millî parkların listesi aşağıdaki tabloda gösterilmiştir. 
Tablo 1. İlan Tarihlerine Göre Türkiye'deki Millî Parkların Listesi

\begin{tabular}{|c|c|c|c|}
\hline Millî Parkın Adı ve Bulunduğu İl & Yıl & Millî Parkın Adı ve Bulunduğu İl & Yıl \\
\hline 1. Yozgat Çamlığı MP (Yozgat) & 1958 & 24. Kaçkar Dağları MP (Rize-Artvin) & 1994 \\
\hline 2. Karatepe-Aslantaş MP (Osmaniye) & 1958 & 25. Karagöl-Sahara MP (Artvin) & 1994 \\
\hline 3. Soğuksu MP (Ankara) & 1959 & 26. Aladağlar MP (Niğde-Adana-Kayseri) & 1995 \\
\hline 4. Kuşcenneti MP (Balıkesir) & 1959 & 27. Marmaris MP (Muğla) & 1996 \\
\hline 5. Uludağ MP (Bursa) & 1961 & 28. Saklıkent MP (Muğla-Antalya) & 1996 \\
\hline 6. Yedigöller MP (Bolu) & 1965 & 29. Troya Tarihi MP (Çanakkale) & 1996 \\
\hline $\begin{array}{l}\text { 7. Dilek Yarımadası-Büyük Menderes Deltası } \\
\text { MP (Aydın) }\end{array}$ & 1966 & 30. Honaz Dağı MP (Denizli) & 1998 \\
\hline 8. Spil Dağ1 MP (Manisa) & 1968 & 31. Küre Dağları MP (Kastamo & 2000 \\
\hline 9. Kızıldağ MP (Isparta) & 1969 & $\begin{array}{l}\text { 32. Sarıkamış-Allahuekber Dağları MP } \\
\text { (Kars-Erzurum) }\end{array}$ & 2004 \\
\hline 10. Gül & 1970 & 33. Ağr1 Dağ1 MP (Ağr1-Iğdır) & 2004 \\
\hline 11. Kovada Gölü MP (Isparta) & 1970 & 34. Gala Gölü MP (Edirne) & 2005 \\
\hline 12. Munzur Vadisi MP (Tunceli) & 1971 & 35. Sultan Sazlığı MP (Kayseri) & 2006 \\
\hline 13. Beydağları Sahil MP (Antalya) & 1972 & 36. Tek Tek Dağları MP (Şanlıurfa) & 2007 \\
\hline 14. Köprülü Kanyon MP (Antalya) & 1973 & $\begin{array}{l}\text { 37. İğneada Longoz Ormanları MP } \\
\text { (Kırklareli) }\end{array}$ & 2007 \\
\hline 15. Il & 1976 & 38. Nene Hatun Tarihi MP (Erzurum) & 2009 \\
\hline $\begin{array}{l}\text { 16.Başkomutan Tarihi MP (Afyonkarahisar- } \\
\text { Kütahya-Uşak) }\end{array}$ & 1981 & 39. Yumurtalık Lagünü MP (Adana) & 2009 \\
\hline 17. Altındere Vadisi MP (Trabzon) & 1987 & $\begin{array}{l}\text { 40. Sakarya Meydan Muharebesi Tarihi MP } \\
\text { (Ankara) }\end{array}$ & 2015 \\
\hline 18. Boğazköy-Alacahöyük MP (Çorum) & 1988 & $\begin{array}{l}\text { 41. Kop Dağı Müdafaası Tarihi MP (Bayburt- } \\
\text { Erzurum) }\end{array}$ & 2016 \\
\hline 19. Nemrut Dağı MP (Adıyaman-Malatya) & 1988 & $\begin{array}{l}\text { 42. Malazgirt Meydan Muharebesi Tarihi MP } \\
\text { (Muş) }\end{array}$ & 2018 \\
\hline 20. Beyşehir Gölü MP (Konya) & 1993 & $\begin{array}{l}\text { 43. İstiklal Yolu Tarihi MP (Kastamonu- } \\
\text { Çankırı) }\end{array}$ & 2018 \\
\hline 21. Kazd & 1994 & 44. Botan Vadisi MP (Siirt) & 2019 \\
\hline 22. Altınbeşik Mağarası MP & 1994 & 45. Hakkâri Cilo ve Sat Dağları MP (Hakkâri) & 2020 \\
\hline 23. Hatila Vadisi MP (Artvin) & 1994 & & \\
\hline
\end{tabular}

Kaynak: T.C. Tarım ve Orman Bakanlığı Doğa Koruma ve Millî Parklar Genel Müdürlüğü, 2021.

Türkiye'de doğa koruma anlayışında son yıllarda önemli kırılmalar yaşanmıştır. Ülkemizdeki korunan alanlara yönelik benimsenen geleneksel salt korumacılık ve merkeziyetçi bir anlayış yaklaşımı giderek değişmiştir. Bu anlayış yerini katılımcı yönetim planlarının hazırlığı ve yerelden yönetim anlayışının benimsenmesine bırakmıştır. Bu yeni yaklaşımda, eğitimin önemli bir yeri vardır. Hiç şüphesiz katılımcı yaklaşım, eğitim ve bilinçlendirmelerle desteklendiğinde, ilgi grupları ile korunan alanlar arasında bir eşgüdüm sağlanabilir (Güneş, 2011). Millî park eğitimi, çevre eğitiminin bir parçasıdır. Bu çerçevede millî parklarda sürdürülen doğal, tarihi ve kültürel temelli bilimsel çevre eğitimleri millî park eğitiminin kapsamını oluşturmaktadır. Millî park eğitiminde, parkların özelliklerini gözlemleme ve onu okumada bireylere özgü bir yaklaşım benimsemeleri ve bunun sonucunda bireylerin sorumluluk kazanmaları hedeflenmektedir. Buna ek olarak, millî park eğitiminin beceri yönü de bulunmaktadır. Bu becerilerden en önemlisi, disiplinler arası düşünme becerileridir. Millî park eğitimi kapsamında doğal, tarihi ve kültürel değerleri bir arada sunularak katılımcıların gelişimi amaçlandığı için disiplinler arası düşünme oldukça önemlidir (Ozaner, 2004).

Millî parklara yönelik öğrencilerin bilgi ve farkındalık düzeylerini arttırmak için eğitim kurumlarına önemli görevler düşmektedir. Özellikle öğretim programlarında, millî parklara yönelik içeriklere yer verilmesi oldukça önemlidir. Buna rağmen millî parklar konusuna, öğretim programlarında yeterli ölçüde yer verilmediği görülmektedir. Bu durum, bireylerin 
ekolojik farkındalığını ortaya çıkarmayı zorlaştırmaktadır. Bu yüzden millî park konuları, öğrenciler ve toplumdaki tüm bireyler tarafından örgün veya yaygın eğitim sistemi içerisinde tanıtılmalı ve uygulama alanı olarak kullanılmalıdır (Kocalar, 2016). Millî park farkındalığ1 açısından öğretmen adaylarının bu konuda iyi yetişmiş olmaları önemli bir başlangıç olacaktır. Çünkü öğretmen adaylarının yetiştirecekleri yeni nesillere etkili bir millî park bilgisi ve farkındalığı kazandırmaları için, ilk önce kendilerinin yeterli düzeyde bilgi ve farkındalığa sahip olmaları beklenmektedir. Bu açıdan düşünüldüğünde, millî parklara yönelik öğretmen adaylarının bilgi ve algı düzeylerinin tespit edilmesi önemlidir.

Türkiye'de millî parkalara yönelik yapılan çalışmalarda genel olarak kullanma, koruma ve değerlendirme, flora incelemesi, fauna incelemesi ve turizmsel olarak değerlendirme gibi konuların daha fazla öne çıktığı görülmektedir. Benzer şekilde, millî parkalara yönelik yapılan çalışmalarda genellikle "doğal" millî parkların daha fazla çalışıldı̆̆ 1 , buna karşın "tarihî" millî parkların ise daha az sayıda çalışıldığı dikkat çekmektedir (Dikmenli, Öztürk-Demirbaş \& Yakar, 2018). Alan yazında millî parklara yönelik yapılan çalışmalara bakıldığında, belirli bir millî parkın potansiyel özelliklerinin farklı açılardan ele alındığı çalışmalar sıklıkla görülmektedir. Buna ek olarak, alan yazında millî parkların nasıl algılandığına ilişskin farklı çalışmaları görmek mümkündür. Türkiye'de millî parkalara yönelik yapılan bu çalışmalar; öğretmenlerin yaşadıkları çevrede bulunan millî parklara ilişkin algılarına (Batur, 2006; Karakaş, 2010), öğrencilerinin yaşadıkları çevrede bulunan millî parklara yönelik algılarına (Deniş, 2007; Öztürk \& Şahbaz, 2017), turistlerin gezdikleri millî parklara ilişkin algılarına (Duman, Tanrısever \& Pamukçu, 2019), emekli göçmenlerin millî parklara ilişkin algılarına (Özkan \& Uzun, 2019), sosyal bilgiler öğretmen adaylarının millî parklara ilişskin tutum ve algılarına (Çetin, Aydemir \& Kara, 2016) ve yerel halkın algılarına (Doğru \& Aydın, 2020) yöneliktir.

Gelecek nesillere yaşanılır bir dünya bırakabilmenin yolu çevreyi korumaktan ve genç kuşaklara çevre eğitimini iyi sağlamaktan geçmektedir. Bu bağlamda çevre eğitimi yapmakla görevli olan öğretmenlere büyük sorumluluk düşmektedir. Bu kabulden yola çıkılarak araştırmada ilk ve ortaokulda öğrencilere çevre eğitimi vermesi beklenen Sınıf, Fen Bilgisi ve Sosyal Bilgiler öğretmen adaylarının millî park algılarını farklı değişkenler açısından ortaya çıkarılması, millî parklara ilişkin başarı düzeylerinin tespiti ve algıları ile başarı düzeyleri arasındaki ilişkinin kontrol edilmesi amaçlanmıştır.

\section{Araştırmanın Amacı}

$\mathrm{Bu}$ araştırmanın amacı, öğretmen adaylarının millî parklara yönelik algı düzeyleri ile bilgi düzeyleri arasında ilişkiyi incelemektir. $\mathrm{Bu}$ amaç çerçevesinde aşağıdaki sorulara cevap aranmıştır:

- Öğretmen adaylarının millî parklara yönelik algı düzeyleri nedir?

- Öğretmen adaylarının millî parklara yönelik bilgi düzeyleri nedir?

- Öğretmen adaylarının millî park algı düzeyleri ile bilgi düzeyleri arasında ilişki var midir? 


\section{YÖNTEM}

\section{Araştırmanın Modeli}

$\mathrm{Bu}$ araştırma ilişkisel tarama modelinde gerçekleştirilmiştir. İlişsisel tarama modeli; iki ya da daha fazla sayıdaki değişken arasında, birlikte değişim varlığı ve/veya derecesini belirlemeyi amaçlayan bir araştırma modelidir (Fraenkel \& Wallen, 2009; Karasar, 2005). Model gereği, değişim varlığı veya derecesini belirlemek için öğretmen adaylarının millî parklara yönelik algı ve bilgi düzeyleri ilişkisel olarak çözümlemiştir. İlişkisel çözümleme, korelasyon türü ilişkiler veya karşılaştırma yolu ile elde edilen ilişkilerdir (Karasar, 2005, s. 81).

\section{Katılimcilar}

Araştırmanın katılımcıları, 2016-2017 eğitim-öğretim yılı bahar yarıyılında Kırşehir Ahi Evran Üniversitesi Eğitim Fakültesi Sınıf Eğitimi, Sosyal Bilgiler Eğitimi ve Fen Bilgisi Eğitimi programlarına devam eden 1, 2, 3. ve 4. sınıf öğrencilerinden oluşmaktadır. MPAÖ, 2016-2017 bahar yarıyılında Kırşehir Ahi Evran Üniversitesi Eğitim Fakültesi’nde öğrenim gören farklı sınıf düzeylerinde 711 öğretmen adayına uygulanmıştır. Katılımcıların demografik dağılımı Tablo 2'de gösterilmiştir.

Tablo 2. Araştırmaya Katılan Öğretmen Adaylarının Demografik Özellikleri ( $n=711)$

\begin{tabular}{|c|c|c|c|c|c|c|c|}
\hline \multicolumn{2}{|c|}{ Cinsiyet } & \multicolumn{2}{|l|}{ Anabilim Dalı } & \multicolumn{2}{|c|}{ Sınıf Düzeyi } & \multicolumn{2}{|c|}{ Millî Park Gezme Durumu } \\
\hline Kadın & $\% 74,7$ & Sınıf Eğitimi & $\% 38,2$ & 1. Sinıf & $\% 22,4$ & Evet & $\% 48,9$ \\
\hline Erkek & $\% 25,3$ & Sosyal Bilgiler & $\% 29,9$ & 2. Sinif & $\% 26$ & Hayır & $\% 51,1$ \\
\hline & & Fen Bilgisi & $\% 31,9$ & 3. Sinıf & $\% 28,8$ & & \\
\hline & & & & 4. Sinif & $\% 22,8$ & & \\
\hline
\end{tabular}

\section{Verilerin Toplanması}

İlişkisel tarama modellerinde en az iki değişken arasındaki değişimin varlığı ve derecesi belirlenmeye çalışıldığı için, bu araştırmada iki farklı veri toplama aracı kullanılmıştır. Bu veri toplama araçlarından birincisi katılımcıların millî parklara yönelik bilgi düzeylerini tespit etmek için geliştirilen başarı testidir. Millî parklar gibi özel bir konuya ilişkin çalışma grubunun bilgi düzeylerinin belirlenmesi önemli olduğu için bu veri toplama aracı geliştirilmiştir. İkincisi ise katılımcıların millî parklara yönelik alg1 düzeylerini tespit etmek için geliştirilen alg1 ölçeğidir. Veri toplama araçlarına bağlı olarak çalışma grubunun bilgi ve algi düzeyleri arasındaki ilişki yorumlanmıştır.

Araştırma kapsamında ilk olarak öğretmen adaylarının millî park bilgi düzeylerini ölçmeye yönelik çoktan seçmeli beş seçenekli Millî Park Başarı Testi (MPBT) hazırlanmıştır. MPBT hazırlanırken araştırmacılar tarafından ilk önce bir belirtke tablosu hazırlanmıştır. Bu doğrultuda 30 adet çoktan seçmeli ve beş seçenekli sorudan oluşan madde havuzu oluşturulmuştur. Test maddelerine yönelik biri ölçme değerlendirme, diğeri de coğrafya eğitimi alan uzmanı olmak üzere iki farklı uzmandan görüşler alınmış ve uzmanların önerileri doğrultusunda gerekli düzenlemeler yapılmıştır. Yapılan madde analizine göre, ayırt edicilik düzeyleri düşük olan 4 madde testten çıkartılmıştır. Buna göre, başarı testinin ayırt edicilik kat sayısının 0,35 ile 0,46 arasında değitiği ve güçlük katsayısının ise 0,48 olduğu belirlenmiştir. Ayrıca başarı testinin iç tutarlılık katsayısı (Kr-20) 0,763 olarak hesaplanmıştır. Yapılan madde analizlerinden sonra, son şekli verilen MPBT çalışma grubuna uygulanarak çalışma grubunu oluşturan öğretmen adaylarının millî park bilgi düzeyleri belirlenmiştir. 
Araştırmanın ikinci aşamasında, öğretmen adaylarının millî park algılarının belirlenebilmesi için araştırmacılar tarafından geliştirilen Millî Park Algı Ölçeği (MPAÖ) kullanılmıştır. Bu ölçek 31 madde ve 3 boyuttan oluşmaktadır. MPAÖ'nün alt boyutları; eğitimsel değer, özyeterlilik inancı ve seçimleyici algıdır. Bu çalışma için ölçek iç tutarlık testi Cronbach's Alpha=.739 olarak hesaplanmıştır.

\section{Verilerin Analizi}

Araştırmacılar tarafından geliştirilen algı ölçeği ve başarı testine verilen yanıtlara göre; öğretmen adaylarının millî park algı ve bilgi düzeyleri belirlenmiştir. Öğretmen adaylarının millî park algı düzeylerinin hesaplanmasında aritmetik ortalama ve standart sapmalar kullanılmıştır. Bu doğrultuda öğretmen adaylarının alg1 düzeylerinin belirlenmesinde ankette kullanılan 5'li likert ölçeğine uygun olarak; düşük, orta ve yüksek düzeyde puan aralıkları kullanılmıştır. Öğretmen adaylarının millî park algı düzeyleri verilirken ilk olarak öğretmen adaylarının genel algı düzeyleri verilmiş, ardından ölçeğin alt boyutları doğrultusunda her bir boyutun düzeyi ayrı olarak verilmiştir. Öğretmen adaylarının millî park alg1 ve bilgi düzeyleri ile değişkenler arasında anlamlı bir fark olup olmadığını belirlemek için t-testi ve Varyans Analizi kullanılmıştır.

Öğretmen adaylarının millî parklara yönelik algı düzeyleri ile bilgi düzeyleri arasında anlamlı bir ilişki olup olmadığını belirlemek için, basit korelasyon analizi yapılmıştır. Basit korelasyon analizinde, korelasyon katsayısı $-1,00$ ile 1,00 arasında değerler alır. Korelasyon katsayısının 1,00 olması mükemmel pozitif bir ilişkiyi, $-1,00$ olması mükemmel negatif bir ilişkiyi, 0,00 olması da ilişkinin olmadığını gösterir. Korelasyon katsayısının 0,70-1,00 arasında olması, yüksek; 0,30-0,70 arasında olması, orta; 0,00-0,30 olması ise düşük düzeyde bir ilişki olarak tanımlanabilir (Büyüköztürk, 2002, s. 32). Araştırmada anlamlılık düzeyi $\mathrm{p}<.05$ olarak alınmıştır. Öğretmen adaylarının millî parklara yönelik bilgi düzeylerini ortaya çıkarmak için yapılan analizlerde düşük, orta ve yüksek olmak üzere üç düzeyli bir aralık belirlenmiştir. Buna göre; 0-8,67 arası değerler düşük, 8,68-17,34 arası değerler orta ve son olarak 7,35-26,0 arası değerler ise yüksek bilgi düzeyini oluşturmaktadır. Öğretmen adaylarının bilgi düzeyleri bu aralıklara göre analiz edilerek yorumlanmıştır.

\section{BULGULAR}

Bu bölümde, ilk olarak öğretmen adaylarının millî parklara yönelik algı düzeyleri, daha sonra millî parklara yönelik bilgi düzeyleri, son olarak ise milli parklara yönelik algı ve bilgi düzeyleri arasındaki ilişki verilmiştir.

Tablo 3. Öğretmen Adaylarının Millî Parklara Yönelik Algı Düzeyi Sonuçları

\begin{tabular}{lccl}
\hline Kategoriler & $\overline{\mathbf{X}}$ & \multicolumn{1}{c}{ SS } & \multicolumn{1}{c}{ Aralıklar } \\
\hline Eğitimsel Değer Algıs1 & 48,50 & 6,87 & $14-29$ (Düşük) \\
& & & $30-44$ (Orta) \\
& & & $45-60$ (Yükssek) \\
\hline Özyeterlilik İnanc1 & 23,52 & 4,64 & $7-16$ (Düşük) \\
& & & $17-25$ (Orta) \\
& & & $26-36$ (Yüksek) \\
\hline Seçimleyici Alg1 & 37,00 & 3,94 & $21-30$ (Düşük) \\
& & & $31-39$ (Orta) \\
& & & $40-48$ (Yüksek) \\
\hline Toplam & 109,03 & 10,68 & $36-87$ (Düşük) \\
& & & $88-111$ (Orta) \\
& & & $112-136$ (Yüksek) \\
\hline
\end{tabular}


Tablo 3'te, öğretmen adaylarının millî park algı düzeyleri ilk olarak genel algı düzeyinde, ardından algı ölçeğinin alt boyutları düzeyinde gösterilmiştir. Buna göre, öğretmen adaylarının genel millî park algılarının orta düzeyde olduğu tespit edilmiştir. Ölçeğin alt boyutları açısından bakıldığında, eğitimsel boyutta yüksek algıya sahip olan öğretmen adaylarının, özyeterlilik ve seçimsel algı boyutlarında ise orta düzeyde algıya sahip oldukları belirlenmiştir.

Tablo 4. Katılımcıların Cinsiyetine Göre Millî Park Algı Düzeyleri Puanlarının Bağımsız Gruplar t-Testi Sonuçları

\begin{tabular}{lllllll}
\hline Kategoriler & Cinsiyet & $\mathbf{n}$ & $\overline{\mathbf{X}}$ & $\mathbf{S}$ & $\boldsymbol{t}$ & $\boldsymbol{p}$ \\
\hline Eğitimsel Değer & Kadın & 531 & 48,49 & 6,64 &,- 117 & 0,907 \\
& Erkek & 180 & 48,56 & 7,53 & & \\
\hline Özyeterlik İnancı & Kadın & 531 & 23,01 & 4,53 & $-5,065$ & $0,000^{*}$ \\
& Erkek & 180 & 25,01 & 4,66 & & \\
\hline Seçimleyici Alg1 & Kadın & 531 & 36,92 & 3,77 &,- 870 & 0,385 \\
& Erkek & 180 & 37,22 & 4,40 & & \\
\hline Toplam & Kadın & 531 & 108,43 & 10,40 & $-2,571$ & $0,010^{*}$ \\
& Erkek & 180 & 110,79 & 11,31 & & \\
\hline *p $<.05$ & & & & & &
\end{tabular}

Tablo 4'te gösterildiği gibi, katılımcıların cinsiyetlerine göre genel millî park algı düzeyi puanları arasında fark olup olmadığını gösteren analiz sonucu incelendiğinde, kadın ve erkek öğretmen adayları arasında istatistiksel olarak anlamlı bir farkın olduğu görülmektedir. Buna göre, erkek öğretmen adaylarının genel millî park algı düzeylerinin (110.79), kadın öğretmen adaylarının genel millî park alg1 düzeylerinden (108.43) daha yüksek olduğu sonucuna ulaşılmıştır. Kategoriler açısından bakıldığında, öğretmen adaylarının sadece özyeterlik inancı düzeyi puanlarının kız ve erkek öğretmen adayları arasında istatistiksel olarak anlamlı olduğu görülmektedir. Buna göre, erkek öğretmen adaylarının özyeterlik inancı düzeylerinin (25.01), kadın öğretmen adaylarının özyeterlik inancı düzeylerinden (23.01) daha yüksek olduğu tespit edilmiştir.

Tablo 5. Öğretmen Adaylarının Anabilim Dallarına Göre Millî Park Algı Düzeylerine İlişkin ANOVA Sonuçları

\begin{tabular}{|c|c|c|c|c|c|c|c|}
\hline Kategoriler & Anabilim Dalı & $\mathbf{n}$ & $\overline{\mathbf{X}}$ & $\mathbf{S}$ & $F$ & $p$ & $\begin{array}{c}\text { Fark } \\
\text { Kaynağı }\end{array}$ \\
\hline \multirow[t]{3}{*}{ Eğitimsel Değer } & Sınıf Eğitimi (1) & 272 & 49,34 & 6,16 & 5,825 & 0,003 & $1-3$ \\
\hline & Sosyal Bilgiler (2) & 212 & 48,75 & 8,63 & & & \\
\hline & Fen Bilgisi (3) & 227 & 47,28 & 5,55 & & & \\
\hline \multirow[t]{3}{*}{ Özyeterlik İnancı } & Sınıf Eğitimi (1) & 272 & 22,46 & 4,71 & 11,764 & 0,000 & $1-2$ \\
\hline & Sosyal Bilgiler (2) & 212 & 24,10 & 4,64 & & & $1-3$ \\
\hline & Fen Bilgisi (3) & 227 & 24,24 & 4,32 & & & \\
\hline \multirow[t]{3}{*}{ Seçimleyici Alg1 } & Sınıf Eğitimi (1) & 272 & 37,01 & 4,12 & 12,377 & 0,000 & $1-2$ \\
\hline & Sosyal Bilgiler (2) & 212 & 36,04 & 3,94 & & & $1-3$ \\
\hline & Fen Bilgisi (3) & 227 & 37,88 & 3,49 & & & $2-3$ \\
\hline \multirow[t]{3}{*}{ Toplam } & Sınıf Eğitimi (1) & 272 & 108,81 & 10,30 & 0,211 & 0,810 & \\
\hline & Sosyal Bilgiler (2) & 212 & 108,90 & 12,03 & & & \\
\hline & Fen Bilgisi (3) & 227 & 109,40 & 9,77 & & & \\
\hline
\end{tabular}

Tablo 5 incelendiğinde, anabilim dalı değişkenine göre öğretmen adaylarının genel millî park algısının farklılık göstermediği belirlenmiştir. Buna rağmen, alt kategoriler bazında öğretmen adaylarının millî park algı düzeylerinde anabilim dalı değişkenine göre farklılık olduğu tespit edilmiştir. Buna göre eğitimsel değer kategorisinde Sınıf Eğitimi ile Fen Bilgisi anabilim dallarında eğitim gören öğretmen adaylarının eğitimsel değer algı düzeyi puanlarının anlamlı düzeyde farklılaştığı belirlenmiştir $(F=5,825 ; p<0,01)$. Özyeterlik inancı kategorisinde, Sinıf Eğitimi ile Sosyal Bilgiler ve Sınıf Eğitimi ile Fen Bilgisi anabilim dallarında eğitim gören 
öğretmen adaylarının alg1 düzeyi puanlarının anlamlı düzeyde farklılaştığı belirlenmiştir $(\mathrm{F}=11,764 ; \mathrm{p}<0,01)$. Son olarak, seçimleyici alg1 kategorisinde, Sınıf Eğitimi ile Sosyal Bilgiler, Sınıf Eğitimi ile Fen Bilgisi ve Sosyal Bilgiler ile Fen Bilgisi anabilim dallarında eğitim gören öğretmen adaylarının algı düzeyi puanlarının anlamlı düzeyde farklılaştığ belirlenmiştir $(\mathrm{F}=12,377 ; \mathrm{p}<0,01)$.

Tablo 6. Öğretmen Adaylarının Sınıf Düzeyine Göre Millî Park Algı Düzeylerine İlişkin ANOVA Sonuçları

\begin{tabular}{|c|c|c|c|c|c|c|c|}
\hline Kategoriler & Sınıf Düzeyi & n & $\overline{\mathbf{X}}$ & $\mathbf{S}$ & $\boldsymbol{F}$ & $p$ & $\begin{array}{c}\text { Fark } \\
\text { Kaynă̆l }\end{array}$ \\
\hline \multirow[t]{4}{*}{ Eğitimsel Değer } & 1. $\sin 1 f(1)$ & 159 & 47,37 & 7,54 & 2,754 & 0,042 & $1-4$ \\
\hline & 2.sinif (2) & 185 & 48.67 & 6,74 & & & \\
\hline & 3. $\sin 1 f(3)$ & 205 & 48,41 & 7,26 & & & \\
\hline & 4. $\operatorname{sinif}(4)$ & 162 & 49,55 & 5,06 & & & \\
\hline \multirow[t]{5}{*}{ Özyeterlik İnancı } & 1. $\operatorname{sinif}(1)$ & 159 & 22,46 & 4,67 & 18,759 & 0,000 & $1-3$ \\
\hline & 2.sinif (2) & 185 & 22,29 & 4,62 & & & $1-4$ \\
\hline & 3. $\sin 1 f(3)$ & 205 & 23,86 & 4,53 & & & $2-3$ \\
\hline & 4. $\sin 1 f(4)$ & 162 & 25,52 & 4,00 & & & $2-4$ \\
\hline & & & & & & & $3-4$ \\
\hline \multirow[t]{4}{*}{ Seçimleyici Alg1 } & 1. $\sin 1 f(1)$ & 159 & 37,03 & 3,61 & ,366 & 0,778 & - \\
\hline & 2.sinif (2) & 185 & 37,09 & 3,89 & & & \\
\hline & 3. $\sin 1 f(3)$ & 205 & 36,76 & 4,03 & & & \\
\hline & 4. $\sin 1 f(4)$ & 162 & 37,15 & 4,19 & & & \\
\hline \multirow[t]{4}{*}{ Toplam } & 1. $\sin 1 f(1)$ & 159 & 106,88 & 11,20 & 7,725 & 0,000 & $1-4$ \\
\hline & $2 . \sin 1 f(2)$ & 185 & 108,06 & 10,30 & & & $2-4$ \\
\hline & 3. $\operatorname{sinif}(3)$ & 205 & 109,04 & 11,53 & & & $3-4$ \\
\hline & 4. $\sin 1 f(4)$ & 162 & 112,12 & 8,59 & & & \\
\hline
\end{tabular}

Tablo 6 incelendiğinde, sınıf düzeyi değişkenine göre öğretmen adaylarının genel millî park algısının 1., 2. ve 3. sınıf düzeyleri ile 4. sınıf düzeyi arasında farklılık gösterdiği belirlenmiştir $(\mathrm{F}=7,725 ; \mathrm{p}<0,01)$. Kategoriler bazında bakıldığında, seçimleyici algı kategorisi hariç diğer tüm kategorilerde, sınıf düzeyi değişkenine göre öğretmen adaylarının millî park algısının farklılık gösterdiği tespit edilmiştir. Genel olarak düşünüldüğünde, öğretmen adaylarının millî park algı düzeyinin sınıf düzeyi artıkça anlamlı biçimde arttığı sonucuna ulaşılmıştır.

Tablo 7. Katılımcıların Millî Parkı Gezme Durumuna Göre Millî Park Algı Düzeyleri Puanlarının t-Testi Sonuçları

\begin{tabular}{llccccc}
\hline Kategoriler & Gezme Durumu & $\mathbf{n}$ & $\overline{\mathbf{X}}$ & $\mathbf{S}$ & $\boldsymbol{t}$ & $\boldsymbol{p}$ \\
\hline Eğitimsel Değer & Evet & 348 & 48,83 & 6,62 &, 957 & 0,339 \\
& Hayır & 363 & 48,32 & 7,12 & & \\
\hline Özyeterlik İnanc1 & Evet & 348 & 24,55 & 4,39 & 6,112 & 0,000 \\
& Hayır & 363 & 22,41 & 4,69 & & \\
\hline Seçimleyici Alg1 & Evet & 348 & 37,12 & 3,95 & 1,130 & 0,259 \\
& Hayır & 363 & 36,78 & 3,99 & & \\
\hline Toplam & Evet & 348 & 110,50 & 10,72 & 3,659 & 0,000 \\
& Hayır & 363 & 107,52 & 10,54 & & \\
\hline
\end{tabular}

Tablo 7'de gösterildiği gibi, katılımcıların herhangi bir millî parkı gezme durumlarına göre genel millî park algı düzeyi puanları arasında fark olup olmadığını gösteren analiz sonucu incelendiğinde, herhangi bir millî parkı gezen ve gezmeyen öğretmen adayları arasında istatistiksel olarak anlamlı bir farkın olduğu görülmektedir. Buna göre, herhangi bir millî parkı gezen öğretmen adaylarının genel millî park alg1 düzeylerinin $(\bar{X}=110,50)$, herhangi bir millî park1 gezmeyen öğretmen adaylarının genel millî park alg1 düzeylerinden $(\bar{X}=107,52)$ daha yüksek olduğu sonucuna ulaşılmıştır. Kategoriler bazında bakıldığında ise sadece özyeterlik inancı kategorisinde, herhangi bir millî parkı gezen ve gezmeyen öğretmen adayları arasında 
istatistiksel olarak anlamlı bir farkın olduğu görülmektedir. Genel olarak herhangi bir millî parkı gezmiş olan öğretmen adaylarının gezmemiş olanlara göre algıları anlamlı şekilde farklılık göstermiştir.

Tablo 8. Öğretmen Adaylarının Millî Park Bilgi Düzeylerine Yönelik Yapılan Başarı Testi Sonuçları

\begin{tabular}{cccccccc} 
Bilgi Düzeyi & $\mathbf{n}$ & Min & Max & $\overline{\mathbf{X}}$ & $\mathbf{S}$ & Mod & Medyan \\
\cline { 2 - 6 } & .00 & 14 & 6.725 & 3.582 & 9 & 7 \\
\hline
\end{tabular}

Öğretmen adaylarının millî park bilgi düzeylerine yönelik yapılan başarı testi sonuçları Tablo 8 'de gösterilmiştir. Buna göre ögretmen adaylarının millî parklara yönelik başarı testinden aldıkları başarı ortalamaları $X^{-}=6,725^{\prime}$ tir. $B u$ sonuç, millî park bilgi testinde bulunan 26 sorudan öğretmen adaylarının ortalamalarının 6,725'ini doğru olarak yanıtladıklarını göstermektedir. Bu durum, öğretmen adaylarının millî park bilgi düzeylerinin düşük olduğunun bir göstergesi olarak belirlenmiştir.

Tablo 9. Öğretmen Adaylarının Başarı Düzeylerinin Cinsiyet Değişkenine Göre t-Testi Sonuçları

\begin{tabular}{lccccc}
\hline Cinsiyet & $\mathbf{n}$ & $\overline{\mathbf{X}}$ & $\mathbf{S}$ & $\mathbf{t}$ & $\mathbf{p}$ \\
\hline K1z & 531 & 7.09 & 3.29897 & -.112 & \multirow{2}{*}{.911} \\
Erkek & 180 & 7.12 & 3.29894 & & \\
\hline
\end{tabular}

Öğretmen adaylarının millî park bilgi düzeyi ile cinsiyetleri arasındaki ilişkiye yönelik yapılan t-testi sonuçları Tablo 9'da gösterilmiştir. Buna göre, kadın öğretmen adayları $\left(\mathrm{X}^{-}=7,09\right.$; $\mathrm{ss}=3,29897)$ ile erkek öğretmen adaylarının $\left(\mathrm{X}^{-}=7,12\right.$; ss=3,29894) millî park bilgi düzeyi arasında anlamlı bir farklılık olmadığı sonucuna ulaşılmıştır $(\mathrm{t}=-, 112 ; \mathrm{p}<0.05)$.

Tablo 10. Öğretmen Adaylarının Başarı Düzeylerinin Anabilim Dalı Değişkenine Göre Varyans Analizi Sonuçları

\begin{tabular}{lcccccc}
\hline Bölüm & $\mathbf{n}$ & $\overline{\mathbf{X}}$ & $\mathbf{S}$ & \multicolumn{2}{c}{ ANOVA } & Fark \\
& & & & $\mathrm{F}$ &, 000 & $1-2$ \\
Sinıf Eğitimi (1) & 272 & 8,6801 & 2,43072 & 84,628 & & $1-3$ \\
Sosyal Bilgiler (2) & 212 & 7,1085 & 3,46171 & & & \\
Fen Bilgisi (3) & 227 & 5,2115 & 3,04672 & & & \\
Toplam & 711 & 7,1041 & 3,29667 & & & \\
\hline
\end{tabular}

Tablo 10'da, öğretmen adaylarının millî parklara yönelik başarı düzeylerinin öğrenim gördükleri anabilim dalı değişkenine göre varyans analizi sonuçları gösterilmiştir. Bu sonuçlara göre, öğretmen adaylarının millî park başarı düzeyleri ile öğrenim gördükleri anabilim dalları arasında anlamlı bir ilişkinin olduğu görülmektedir $[\mathrm{F}(2-708)=84,628 ; \mathrm{p}<0.05]$. Öğretmen adaylarının millî park başarı düzeyleri Sınıf, Sosyal Bilgiler ve Fen Bilgisi eğitimi arasında Sınıf Eğitimi lehine anlamlı farklılık olduğu tespit edilmiştir.

Tablo 11. Öğretmen Adaylarının Başarı Düzeylerinin Sınıf Düzeyine Göre Varyans Analizi Sonuçları

\begin{tabular}{lcccccc} 
Sinıf Düzeyi & $\mathbf{n}$ & $\overline{\mathbf{X}}$ & $\mathbf{S}$ & \multicolumn{2}{c}{ ANOVA } & Fark \\
\cline { 1 - 3 } & & & & $\mathrm{F}$ & $\mathrm{p}$ & \\
1.Sinıf(1) & 159 & 6,5912 & 3,38503 & 6,258 &, 000 & $2-4$ \\
2.Sinıf(2) & 185 & 6,6811 & 3,83220 & & & \\
3.Sinıf(3) & 205 & 7,1951 & 2,71542 & & & \\
4.Sinif (4) & 162 & 7,9753 & 3,05224 & & & \\
Toplam & 711 & 7,1041 & 3,29667 & & & \\
\hline
\end{tabular}


Öğretmen adaylarının bilgi düzeylerinin sınıf düzeyine göre varyans analizi sonuçları Tablo 11 'de gösterilmiştir. Bu sonuçlar, öğretmen adaylarının millî park başarı düzeyleri ile öğrenim gördükleri sınıf düzeylerinin arasında anlamlı bir ilişki olduğunu göstermektedir [F(3$707)=6,258, p<0.05]$. Buna göre; öğretmen adaylarının millî park bilgi düzeylerinde, 1 . sınıf $(\bar{x}=6,59 ;$ ss $=3,38)$ ile 4 . sinıf $(\bar{x}=7,97 ; s s=3,05)$ öğretmen adayları arasında 4. sinıf lehine anlamlı bir ilişki olduğu yönündedir. Benzer şekilde 2. sınıf öğretmen adayları $(\bar{x}=6,68$; ss $=3,38)$ ile 4 . sinıf $(\bar{x}=7,97 ; s s=3,05)$ ögretmen adayları arasında da anlamlı ve 4. sinıf lehine bir ilişki olduğu tespit edilmişstir.

Tablo 12. Öğretmen Adaylarının Başarı Düzeylerinin Millî Park Gezme Durumuna Göre t-Testi Sonuçları

\begin{tabular}{lccccc}
\hline Millî Park Gezme Durumu & $\mathbf{n}$ & $\overline{\mathbf{X}}$ & $\mathbf{S}$ & $\mathbf{t}$ & $\mathbf{p}$ \\
\hline Evet & 348 & 7,1826 & 3,18492 & & .121 \\
Hayır & 363 & 7,1523 & 3,37175 & & .90 \\
\hline
\end{tabular}

Tablo 12’de, öğretmen adaylarının başarı düzeylerinin millî park gezme durumuna göre t-testi sonuçları gösterilmiştir. Bu sonuçlar incelendiğinde, herhangi bir millî parkı gezen öğretmen adayları ile gezmeyenler arasında anlamlı bir ilişkinin bulunmadığı sonucuna ulaşılmıştır $(\mathrm{t}=.121, \mathrm{p}>0,05)$.

Tablo 13. Öğretmen Adaylarının Algı ve Bilgi Düzeyi Arasındaki İlişki ile İlgili Korelasyon Katsayısı Sonuçları

\begin{tabular}{lccc}
\hline Değişkenler & & Algı Düzeyi & Bilgi Düzeyi \\
\hline Algı Düzeyi & $\mathrm{r}$ & 1 &, $143^{* *}$ \\
& $\mathrm{p}$ & - &, 000 \\
& $\mathrm{n}$ & 711 & 711 \\
\hline Bilgi Düzeyi & $\mathrm{r}$ &, $143^{* *}$ & 1 \\
& $\mathrm{p}$ &, 000 & - \\
& $\mathrm{n}$ & 711 & 751 \\
\hline
\end{tabular}

$* * p<0.01$

Öğretmen adaylarının algı ve bilgi düzeyi arasındaki ilişki ile ilgili korelasyon katsayısı sonuçları Tablo 13'te gösterilmiştir. Bu sonuçlara göre, öğretmen adaylarının millî parklara yönelik başarı düzeyleri ile algı düzeyleri arasında düşük düzeyde, pozitif yönlü ve anlamlı bir ilişki olduğu bulunmuştur $(\mathrm{r}=.143, \mathrm{p}<0.01)$. Buna göre, öğretmen adaylarının millî parklara yönelik alg1 düzeyi arttıkça, millî parklara yönelik bilgi düzeylerinin de arttığı söylenebilir.

\section{SONUÇ, TARTIŞMA VE ÖNERİLER}

Üç farklı aşamada sürdürülen bu araştırmada, ilk olarak öğretmen adaylarının millî parklara yönelik algı düzeyleri, ikinci olarak öğretmen adaylarının millî parklara yönelik bilgi düzeyleri ve son olarak ise öğretmen adaylarının millî parklara yönelik algı ve bilgi düzeyleri arasındaki ilişkinin ne düzeyde olduğu belirlenmiştir.

Araştırma sonucunda, öğretmen adaylarının millî park algılarının orta düzeyde olduğu belirlenmiştir. Bunun yanı sıra, öğretmen adaylarının millî parklara yönelik algılarının alt boyutlarından olan eğitimsel boyutta yüksek algıya, özyeterlilik ve seçimsel algı boyutlarında ise orta düzeyde bir algıya sahip oldukları sonucuna ulaşılmıştır. Sert (2017) tarafından yapılan çalışmada, 2009-2017 yılları arasında toplam 596 Fen Bilgisi öğretmen adayı ile "Türkiye'nin Biyolojik Zenginlikleri” dersi kapsamında doğa ve biyoçeşitlilik eğitimi amacı ile millî park 
gezileri yapılmıştır. Çalışmanın sonucunda gezilere katılan aday öğretmenlerin çevre korumaya ve kuşlara yönelik farkındalıklarında artış gözlendiği sonucuna ulaşılmıştır. Buna ek olarak, çevresinde herhangi bir millî park bulunan kişilerin bu alanlara yönelik algılarının yüksek olması beklenebilir bir durumdur. Millî parkların, çevresinde yaşayan insanlar tarafindan ilgi çekmesinde, millî parkların içinde dinlenme, eğlenme, yeme-içme ve spor gibi tesislerin yer almasının etkisi olabilir (Akbulut, Atmış \& Günşen, 2015). Benzer şekilde, Öztürk ve Şahbaz (2017) tarafından yapılan çalı̧̧mada, üniversite öğrencilerinin millî park destinasyon imajı algılarının yüksek düzeyde ve olumlu olduğu sonucuna ulaşılmıştır. Buna rağmen yapılan bu araştırmada, üniversite öğrencilerinin genel alg1 düzeylerini düşüren olumsuz ifadeler kullandıkları da tespit edilmiştir.

Öğretmen adaylarının millî park bilgi düzeyleri incelendiğinde; sınıf eğitimi, sosyal bilgiler ve fen bilgisi öğretmen adaylarının başarı testindeki yanıtlarının ortalaması 6,72 olarak bulunmuş olup, bu ortalamanın öğretmen adaylarının başarı düzeylerinin düşük olduğunu göstermektedir. Öz, Bakır ve Yıldırım, (2013) tarafından yapılan fen bilgisi öğretmen adaylarının millî parklarda çevre eğitimine yönelik görüşlerini incelemek amacıyla yapılan çalışmada, öğretmen adaylarının millî parkların çevre eğitimindeki rolünün en fazla ilk elden deneyim veya çevreden öğrenmeyi sağlama olarak gördükleri sonucuna ulaşılmıştır. Buna ek olarak, öğretmen adaylarının büyük çoğunluğunun, öğretmen olduklarında millî parklar konusunda bilgilendirmek için öğrencilerini millî parklara götürmek istedikleri sonucuna ulaşılmıştır. Öğretmen adaylarının millî park bilgi düzeylerinin düşük olmasının nedenlerinden birinin, öğretmen yetiştirme lisans programlarındaki coğrafya ve çevre eğitimine yönelik derslerin azlığ1 ve içerik olarak bu derslerin yeterli olmaması gösterilebilir. Yüksek Öğretim Kurulu'nun 2018 yılında güncellediği öğretmen yetiştirme lisans programları incelendiğinde, millî parklara Sınıf Öğretmenliği ve Sosyal Bilgiler Öğretmenliği lisans programlarında, sadece meslek bilgisi kodlu seçmeli bir dersi olan "Okul Dış1 Öğrenme Ortamları” dersinin içeriğinde yer verildiği görülmektedir. Buna karşın, Fen Bilgisi Öğretmenliği lisans programında ise meslek bilgisi kodlu seçmeli "Okul Dışı Öğrenme Ortamları" dersi ve alan eğitimi kodlu "Fen Öğretiminde Okul Dışı Öğrenme Ortamları” dersinin içeriğinde yer verildiği anlaşılmaktadır (YÖK, 2018). Sınıf Öğretmenliği ve Sosyal Bilgiler Öğretmenliği ders içeriklerinde yalnızca seçmeli bir derste, Fen Bilgisi Öğretmenliği lisans programında ise sadece iki ders kapsamında yer verilen millî parkların öğretmen yetiştirme lisans programlarında çok az yer bulması, öğretmen adaylarının millî park bilgi düzeylerinin düşük olmasının önemli bir nedeni olabilir.

Öğretmen adaylarının millî park alg1 ve bilgi düzeyleri, cinsiyet değişkenine göre incelendiğinde; millî park algı düzeylerinin erkek öğretmen adayları lehine anlamlı farklılık gösterdiği tespit edilmiştir. Buna karşın, öğretmen adaylarının millî park bilgi düzeyleri ile cinsiyetleri arasında anlamlı bir farklılık olmadığı sonucuna ulaşılmıştır. Deniş ve Genç, (2010) tarafından yapılan çalışmada, millî parklar çevresinde yaşayan sekizinci sınıf öğrencilerinin millî parka yönelik tutumları cinsiyete göre anlamlı bir farklılık göstermediği sonucuna ulaşılmıştır. Benzer şekilde, Yaşar ve Şeremet (2008), millî park ziyaretçileri ile gerçekleştirdikleri çalışmalarında cinsiyetin kişilerin millî parklar eğitimine yönelik bilgi, görüş ve bilinç durumları üzerinde bir etkiye sahip olmadığı sonucuna ulaşmışlardır. Millî park bilgi düzeyi ile cinsiyet arasında herhangi bir etkinin olmaması literatürdeki benzer çalışmalarla örtüşmektedir. Buna rağmen, millî park algısı açısından bu çalışmanın sonuçları ile literatürdeki çalışmaların sonuçlarının çelişmesinin nedeni, erkek öğretmen adaylarının millî park gibi yerleri kadın öğretmen adaylarına oranla daha bağımsız gezebilmelerine bağlanabilir. 
Öğretmen adaylarının millî park algı ve bilgi düzeyleri öğrenim gördükleri anabilim dalına göre farklılaşmaktadır. Buna göre, anabilim dalı değişkenine göre öğretmen adaylarının genel millî park algısının farklılık göstermemesine rağmen, öğretmen adaylarının millî park bilgi düzeylerinin Sınıf, Sosyal Bilgiler ve Fen Bilgisi eğitimi arasında Sınıf Eğitimi lehine anlamlı farklılık olduğunu göstermektedir. Öğretmen adaylarının milli parklara yönelik algılarının öğrenim gördükleri anabilim dalına göre farklılık göstermemesinin nedeni, bu öğretmen yetiştirme lisans programlarının benzer ders ve ders içeriklerine sahip olmasıyla ilişkili olabilir. Her üç lisans programlarında da coğrafya ve özellikle çevre eğitimine yönelik dersler yer almaktadır. Buna karşın öğretmen adaylarının millî park bilgi düzeylerinin diğer anabilim dallarına kıyasla Sınıf Eğitimi lehine anlamlı farklılık göstermesi, lisans programlarında yer alan ders içerikleriyle ilişkili olabilir. Çünkü nitelikli sınıf öğretmenlerinin yetiştirilmesi, mesleğin ön hazırlık koşulu olan sınıf öğretmenliği lisans programlarında yer alan derslerin içerikleriyle doğrudan ilişkilidir (Çoban, 2011). 2018-2019 eğitim öğretim y1lı ile uygulamaya konulan yeni lisans ders programlarından biri de sınıf öğretmenliği lisans programıdır. Bu programda; \%46 alan eğitimi dersleri, \%35 meslek bilgisi dersleri ve \%19 genel kültür derslerinin yer aldığı görülmektedir. "Eğitimde Program Dışı Etkinlikler" ve "Okul Dış1 Öğrenme Ortamları” isimli seçmeli dersleri, programa eklenen yeni derslerdendir. Özellikle eğitim-öğretim faaliyetlerinin sadece program ile sınırlı olmadığı düşünüldüğünde, sınıf öğretmenliği lisans programı içerisinde yer alan program dişı etkinliklerin bu dersler aracılığıyla öğretmen adayları tarafından bilinmesi öngörülmektedir (Yurdakal, 2018). Tüm bu faktörlere bağlı olarak, öğretmen adaylarının millî park bilgi düzeylerinin diğer anabilim dallarına kıyasla Sınıf Eğitimi lehine anlamlı farklılık göstermesi anlaşılabilir.

Öğretmen adaylarının millî park algı ve bilgi düzeyleri milli park ziyaret edip etmeme durumuna göre incelendiğinde; herhangi bir millî parkı gezmiş olan öğretmen adaylarının gezmemiş olanlara göre algıları, anlamlı şekilde farklılık göstermiştir. Buna karşın, herhangi bir millı̂ parkı gezen öğretmen adayları ile gezmeyenler arasında millî park bilgi düzeyi açısından anlamlı bir ilişkinin bulunmadığı görülmektedir. Herhangi bir millî parkı gezme durumu, öğretmen adaylarının algı düzeylerinin olumlu anlamda etkilerken, öğretmen adaylarının bilgi düzeylerini ise etkilememektedir. Deniş ve Genç, (2010) tarafından yapılan çalışmada, millî parklar çevresinde yaşayan sekizinci sınıf öğrencilerinin millî parka yönelik tutumları, millî parka daha önce gitmiş olmalarına göre anlamlı bir farklılık göstermektedir. Tubb (2003)'un ortaya koyduğu millî park ziyaretçilerine ziyaret öncesi ve sonrası anket uygulandığında, tutumlarının olumlu yönde değiştiği sonucuyla desteklenmektedir. Yaşar ve Şeremet (2008), çalışmalarında bireylerin millî parka gitme sıklığı arttıkça, millî parka ilişkin bilgi, bilinç ve sorumluluk açısından kazanımların arttığı sonucuna ulaşmışlardır. Bu sonuçlar, tutum üzerinden olmakla birlikte bu çalışmanın sonuçlarıyla örtüşmektedir. Buna karşın Çetin, Aydemir ve Kara (2016) yaptıkları çalışmada, millî parklara yapılan önceki ziyaretlerin öğretmen adaylarının millî parklara yönelik tutumlarını değiştirmediği sonucuna ulaşmıştır.

Öğretmen adaylarının millî park algı ve bilgi düzeyleri, öğrenim gördükleri sınıf düzeyine göre ele alındığında; öğretmen adaylarının sınıf düzeyi artıkça anlamlı biçimde arttığı sonucuna ulaşılmıştır. Yüksek Öğretim Kurulu'nun 2018 y1lında güncellediği öğretmen yetiştirme lisans programları incelendiğinde, ilk sınıf düzeylerinde (1. ve 2. sınıflar), daha çok zorunlu ve genel kültür ile meslek bilgisine yönelik derslerin ağırlıkta olduğu görülmektedir. Buna karşın meslek bilgisi, alan bilgisi ve genel kültüre yönelik seçmeli dersleri 3. ve 4. sınıf düzeylerinde yoğunluk kazandığı dikkat çekmektedir (YÖK, 2018). Milli parkların da içerisinde yer aldığı okul dış1 öğrenme ortamlarının, bu seçmeli dersler içerisinde verildiği düşünüldüğünde, sınıf düzeyi arttıkça öğretmen adaylarının millî park algı ve bilgi düzeylerinin artması buna bağlı olarak 
yorumlanabilir. Ayrıca 3. ve 4. sınıf düzeylerinde okuyan öğretmen adaylarının kendi alanlarına yönelik daha net bir bakış açılarının gelişmiş olması da bu sonucun çıkmasına bağlanabilir.

Öğretmen adaylarının algı ve bilgi düzeyleri arasındaki ilişkiye bakıldığında, öğretmen adaylarının millî parklara yönelik algı düzeyi arttıkça, millî parklara yönelik bilgi düzeylerinin de arttığı sonucuna ulaşılmıştır. Öğretmenler, millî parklarla ilgili etkinliklere yer verdikçe öğrencilerin millî parklara yönelik alg1 düzeylerini artırabilir ve bunun bir sonucu olarak öğrencilerin bilgi düzeyleri de artabilir. Çünkü değişen algılar, var olunan bilgi düzeyini de etkileyecek ve değiştirecektir. Varanci-Uzun'a (2020) göre, millî parklarla ilgili etkinlik yapmadan önce öğretmenler, milli parkın sahip olduğu kaynak değerleri ve parktaki doğal yapının oluşum sürecini önceden öğrencilere aktarmalıdır. Ayrıca millî parklarda etkinlik yapmadan önce olası riskleri de hesaba katmak ve buna göre planlama yapmak, millî park eğitiminde öğrenmelerin başarıya ulaşmasında önemlidir. Tüm bu çıkarımlar, millî parklara ilişkin algının önceden değiştirilmesinin ardından aslında bilgi düzeylerinin de artabileceğine işaret etmektedir.

Millî park eğitimi, çevre eğitimi açısından oldukça önemli bir yere sahiptir. Türkiye'de çevre eğitimi konusunda hem resmi kurum ve kuruluşların hem de eğitim kurumlarında önemli eksiklikler göze çarpmaktadır. Bu eksikliklerin bir sonucu olarak koruma altına alınan alanların çevre kirliliği, aşırı ve plansız kullanımı neticesinde bu alanların ciddi boyutlarda tehdit altında kalmasına neden olmaktadır (Koday, 2017). Koruma altındaki alanların eğitim içerisinde kullanılması, bu alanlara ilişkin bilgi düzeyinin de artmasına neden olabilir. Fakat millî parklar, birçok alanda kullanılabilir olmasına rağmen gezi, ulaşım ve kaynak eksikliği gibi birçok faktöre bağlı olarak, millî parklardan eğitim alanında yeterince faydalanılamamaktadır. $\mathrm{Bu}$ çalışmada, öğretmen adaylarının millî park algı düzeyleri ile bilgi düzeylerinin nasıl olduğu, değişkenlere göre bu düzeylerin değişip değişmediği ve son olarak alg1 ve bilgi düzeyleri arasında bir ilişkinin olup olmadığı belirlenmiştir. Bu çalışma kapsamında, ortaya çıkan sonuçlar çerçevesinde şu önerilerde bulunulabilir:

- Öğretmen adaylarının millî park algı ve bilgi düzeylerini arttırmak için, öğretmen adaylarına yönelik milli parklara neden ihtiyaç duyulduğu, bu alanların neden koruma altında oldukları ve hangi alanlarda kullanıma sunulabileceği ile ilgili farkındalık oluşturulacak farklı etkinlikler hazırlanmalı ve lisans eğitimleri boyunca bu etkinliklere yer verilmelidir.

- Öğretmen adaylarının millî parklara ilişkin algılarını değiştirmek için, toplumda yerleşmiş olan ön yargı ve kalıp düşüncelerin kırılması gerekmektedir. Özellikle kültürel yapı içerisinde, millî parklar gibi koruma altındaki alanların gezilmesine yönelik gündeme getirilen toplumsal cinsiyet rolleri bağlamındaki ayrımcılıklar ortadan kaldırılmalıdır.

- Öğretmen adaylarının öğrenim gördükleri anabilim dalları açısından millî parklara yönelik bilgi düzeyi değişmesine rağmen, algı düzeyleri arasında herhangi bir farklılık olmadığı görülmektedir. Fakat fen bilgisi ve sosyal bilgiler öğretmen adaylarının lisans dersleri ve bu derslerin içerikleri düşünüldüğünde, sınıf eğitimi öğretmen adaylarına oranla daha yüksek olması beklenen bir durumdur. Buna rağmen, öğretmen adaylarının millî park algı düzeylerinde herhangi bir anlamlı farkın çıkmaması, fen bilgisi ve sosyal bilgiler lisans yetiştirme programındaki derslerin okul dışı öğrenme boyutlarının eksik olduğunu göstermektedir. Bu yüzden, özellikle fen bilgisi ve sosyal bilgiler lisans yetiştirme programındaki seçmeli 
derslerden, okul dışı öğrenme ortamlarına yönelik derslerin öğretmen adayları tarafından seçilmesinin sağlanması önerilmektedir.

- Millî parklara yönelik öğretmen adaylarının algı düzeyi arttıkça, bilgi düzeylerinin de arttığ 1 görülmektedir. Bu yüzden öğretmen yetiştirme ders içeriklerinde, öğretmen adaylarının millî parklara yönelik farkındalığını arttırmak için daha fazla etkinliğe yer verilmelidir. Bu çerçevede, lisans dersleri kapsamında millî park gezilerine, millî park fotoğraflarına ve sanal gezi uygulamalarına yer verilmelidir.

- $\mathrm{Bu}$ çalışma, öğretmen adaylarının millî park algı düzeyleri ile bilgi düzeylerini belirlemek için, ilişkisel tarama modelinde gerçekleştirilmiştir. Öğretmen adaylarının millî parklara yönelik algı düzeylerini belirleyen unsurların neler olduğunu daha derinlemesine analiz etmek için, nitel araştırma desenleri kullanılarak bu çerçevede farklı çalışmalar yapılabilir.

\section{KAYNAKÇA}

Akbulut, G., Atmış, E., ve Günşen, H. B. (2015). Farklı ilgi gruplarının milli park algıları üzerine bir değerlendirme: Küre Dağları Millî Parkı örneği. Kastamonu Üniversitesi Orman Fakültesi Dergisi, 15(1), 133-145.

Atik, M. ve Toksöz, A. (2005). Korumada çevre eğitimi. Korumada 50 Yll Sempozyumu, İstanbul 17-18 Kasım 2005, Mimar Sinan Güzel Sanatlar Üniversitesi, ss. 73-82, İstanbul.

Batur, S. (2006). Biyoloji ögrretmenlerinin ve biyoloji dersi alan ögrencilerin Türkiye'nin biyolojik zenginlikleri konusundaki farkında oluşluk düzeylerinin belirlenmesi. (Yüksek Lisans Tezi), Gazi Üniversitesi, Eğitim Bilimleri Enstitüsü, Ankara.

Büyüköztürk, Ş. (2002). İstatistik, araştırma deseni SPSS uygulamaları ve yorum. Pegem Akademi.

Çetin, T., Aydemir, A. ve Kara, H., (2016). Social sciences teacher candidates' awareness of and attitude toward national parks. Atasaoy, E., Efe, R., Jazdzewska, I. ve Yaldır, H. (Editörler), Current advances in education (ss. 514-522), St. Kliment Ohridski University Press.

Çoban, A. (2011). Sınıf öğretmenliği lisans programının değerlendirilmesi. Dicle Üniversitesi Ziya Gökalp Eğitim Fakültesi Dergisi, (16), 28-45.

Deniş, H. ve Genç, H. (2010). İlköğretim sekizinci sınıf öğrencilerinin yaşadıkları çevrede bulunan millî parklara yönelik tutumlarının bazı değişkenlere göre incelenmesi (Isparta İli Örneği). Mehmet Akif Ersoy Üniversitesi Fen Bilimleri Enstitüsü Dergisi, 1, 9-25.

Deniş. H. (2007). İlköğretim sekizinci sinıf öğrencilerinin yaşadıkları çevrede bulunan millî parklara yönelik tutumlarının araştırılması (Isparta ili örneği). (Yüksek Lisans Tezi), Süleyman Demirel Üniversitesi, Fen Bilimleri Enstitüsü, Isparta.

Dikmenli, Y., Öztürk-Demirbaş, Ç., ve Yakar, H. (2018). Türkiye'de millî parklar konusunda hazırlanan lisansüstü tezlerin genel eğilimleri. Uluslararası Toplum Araştırmaları Dergisi, 9(16), 1750-1769. https://doi.org/10.26466/opus.470971.

Doğru, E. ve Aydın, F. (2020). Yerel Halkın Millî Parklara İlişkin Görüşleri: İğneada Longoz Ormanları Millî Park1 Örneği. International Journal of Geography and Geography Education, 25(42), 328-355.

Duman, S., Tanrısever, C. ve Pamukçu, H. (2019). Kastamonu Ilgaz Dağı Millî Parkı'na Gelen Turistlerin Coğrafi İşaretli Ürün Algısı. Journal of Tourism and Gastronomy Studies, 7(2), 818-838.

Fraenkel, Jack R. ve Wallen, Norman E. (2009). How to design and evaluate research in education (Seventh ed.). McGraw-Hill.

Güneş, G. (2011). Korunan alanların yönetiminde yeni bir yaklaşım: katılımcı yönetim planları. Ekonomi Bilimleri Dergisi, 3(1), 47-57. 
Karakaş, A. (2010). Öğretmenlerin yaşadıkları çevrede bulunan millî parka ilişkin tutumlarının incelenmesi (Isparta, Denizli örneği). (Yüksek Lisans Tezi), Mehmet Akif Ersoy Üniversitesi, Fen Bilimleri Enstitüsü, Burdur.

Karasar, N. (2005). Bilimsel araştırma yöntemi. Nobel.

Kocalar, A. O. (2016). Ekolojik farkındalığın arttırılmasında millî parkların rolüne ilişkin öğrenci görüşleri. Avrupa Bilim ve Teknoloji Dergisi, 5(9), 55-61.

Koday, Z. (2017). Çevre, eğitim ve milli parkların önemi. 15. Uluslararası Türk Dünyası Sosyal Bilimler Kongresi, Tebliğler Kitabı, (11-12 Eylül 2017), Türk Dünyası Araştırmaları Vakfı, Moldova.

Kurdoğlu, O. (2007). Dünyada doğayı koruma hareketinin tarihsel gelişimi ve güncel boyutu. Artvin Çoruh Üniversitesi Orman Fakültesi Dergisi, 8(1), 59-76.

Ozaner, F. S. (2002). Millî parklarda çevre eğitim eko-rehber yetiştirilmesinde ve ekoturizmin yaygınlaştırılmasındaki önemi. Turizm Eğitimi Konferansı/Workshop, 11-13 Aralık 2002, Ankara.

Ozaner, F. S. (2003). Ekoturizm Etkinliklerinde ve ekoloji temelli çevre eğitiminde coğrafyanın önemi. E. Ü. Coğrafya Bölümü Sempozyumları 2. Coğrafi Çevre Koruma ve Turizm Sempozyumu, s. 51-54, 16-18 Nisan İzmir.

Ozaner, F. S. (2004). Türkiye'de okul dışı çevre eğitimi ne durumda, neler yapılmalı? Ulusal Ekoloji ve Çevre Kongresi, Bildiri Kitabı (Doğa ve Çevre), Taksim International Abant Palace, Abant İzet Baysal Üniversitesi \& Biyologlar Derneği, (5-8 Ekim 2004), Bolu.

Öz, S., Bakır, S. ve Yıldırım, M. Z. (2013). Fen Bilgisi öğretmen adaylarının millî parklarda çevre eğitimine yönelik görüşleri. Mehmet Akif Ersoy Üniversitesi Ĕgitim Bilimleri Enstitüsü Dergisi, 2(3), 21-35.

Özkan, O. ve Uzun, A. (2019). Kazdağı Millî Park1 ve çevresi (Balıkesir) örneğinde emekli göçmenlerin mekânsal alg1 ve düşünceleri. Coğrafi Bilimler Dergisi, 17(2), 237-259.

Öztürk, Y., ve Şahbaz, R. P. (2017). Algılanan destinasyon imajının tekrar ziyaret niyeti ve tavsiye davranışı üzerine etkisi: Ilgaz Dağı millı̂ Parkı'nda bir araştırma. Journal of Tourism and Gastronomy Studies, 5(2), $3-21$.

Sert, H. (2017). Doğa eğitimi ve turizm alanı olarak Termessos Millî Parkı. Journal of Current Researches on Social Sciences, 2017, 7 (1), 89-102

Şahbaz, R. P. ve Altınay, M. (2015). Türkiye'deki Millî Parkların rekreasyon faaliyetleri açısından değerlendirilmesi. Journal of Tourism and Gastronomy Studies, 3(3), 125-135.

T.C. Tarım ve Orman Bakanlığı Doğa Koruma ve Millî Parklar Genel Müdürlüğü, (2020). Millî parklar. https://www.tarimorman.gov.tr/DKMP/Belgeler/Korunan\%20Alanlar\%20Listesi/1\%20Millî\%20Parklar.pdf.

Tubb, K. N. (2003). An evaluation of the effectiveness of interpretation within Dartmoor National Park in reaching the goals of sustainable tourism development. Journal of Sustainable Tourism, 11(6), 476-498.

Varancı-Uzun, F. (2020). Milli parklar. C. Laçin Şimşek (Ed.), Fen öğretiminde okul dışı öğrenme ortamları İçinde (ss. 213-232), 2. Bask1, Pegem Akademi.

Yaşar, O. (2000). Ülkemizde millî park ve benzer statüdeki alanların dağılımı. Türk Coğrafya Dergisi, 35, 181201.

Yaşar, O. ve Şeremet, M. (2008). Türkiye'deki millî park eğitimi ve millî park eğitimine ilişkin bir araştırma: Gelibolu Yarımadası Tarihi Millî Parkı. Uluslararası Sosyal Araştırmalar Dergisi, 1(5), 910-942.

Yurdakal, İ. H. (2018). Değişen sınıf öğretmenliği lisans program içeriğinin incelenmesi. Ulakbilge Sosyal Bilimler Dergisi, 6(29), 1483-1499.

Yüksek Öğretim Kurulu [YÖK], (2018). Yeni öğretmen yetiştirme lisans programları. https://www.yok.gov.tr/kurumsal/idari-birimler/egitim-ogretim-dairesi/yeni-ogretmen-yetistirme-lisansprogramlari. 


\section{EXTENDED ABSTRACT \\ Preservice Teachers' Perception and Knowledge Levels Towards National Parks: A Relative Study}

\section{Introduction}

Nowadays, there are many nature reserves that have been determined in different ways in many countries. National parks are one of the most common areas in nature conservation areas. National parks provide a serious educational opportunity due to the resources they have and are characterized as open-air laboratories. As of the year 2021, there are 45 national parks in Turkey. National park education is a part of environmental education. Within this framework, the natural, historical and cultural-based scientific environment trainings carried out in national parks constitute the scope of the national park education (Ozaner, 2004). Educational institutions have an important role in increasing the knowledge and awareness of students regarding national parks. In terms of national park awareness, it will be an important start for teacher candidates to be well educated on this subject. Considering the studies on national parks in the literature, there are frequent studies that examine the potential features of a particular national park from different angles.

\section{Purpose}

The aim of this study is to examine the relationship between preservice teachers' perception levels and their knowledge of national parks. For this purpose, the following questions were sought:

- What are the perception levels of preservice teachers towards national parks?

- What is the knowledge level of preservice teachers about national parks?

- Is there a relationship between preservice teachers' national park perception levels and their level of knowledge?

\section{Method}

This research was carried out in relational scanning model. Relational scanning model: it is a research model that aims to determine the existence and / or degree of change between two or more variables (Fraenkel ve Wallen, 2009; Karasar, 2005). As required by the model, to determine the existence or degree of change, preservice teachers' perception and knowledge levels towards national parks were analyzed relationally.

The participants of the study consisted of 711 teacher candidates attending Kırşehir Ahi Evran University Education Faculty Classroom Education, Social Studies Education and Science Education programs in the spring semester of the 2016-2017 academic year. Within the scope of the research, the National Park Achievement Test (NPAT) was prepared with five options to measure the national park knowledge level of teacher candidates. preservice teachers' national park knowledge levels who make up the study group were determined with the success test. In the second stage of the study, the National Park Perception Scale (NPPS), which was developed by the researchers, was used to determine the preservice teachers' national park perceptions. 


\section{Findings}

It has been determined that the preservice teachers' general national park perception is at a moderate level. In terms of the sub-dimensions of the scale, it was determined that teacher candidates who have high perceptions in the educational dimension have medium-level perceptions in the self-efficacy and selective perception dimensions. It is seen that there is a statistically significant difference between female and male teacher candidates. Accordingly, it was concluded that the general national park perception level of male teacher candidates (110.79) was higher than the general national park perception level of female teacher candidates (108.43). The success average of teacher candidates in the achievement test for national parks is $X^{-}==6,725$. This result shows that out of the 26 questions in the national park knowledge test, teacher candidates answered 6.725 of their average correctly. This situation was determined as an indication that the national park knowledge level of the teacher candidates was low. It was found that there is a low level, positive and significant relationship between teacher candidates' achievement levels and their perception levels towards national parks $(\mathrm{r}=$ $.143, \mathrm{p}<0.01)$. Accordingly, it can be said that as the perception level of teacher candidates about national parks increases, their knowledge level about national parks also increases.

\section{Result and Discussion}

It was concluded that as the preservice teachers' perception about national parks increased their knowledge level about national parks also increased. According to Varanc1-Uzun (2020), before organizing activities related to national parks, teachers should convey to students the resource values of the national park and the formation process of the natural structure in the park. All these inferences point to the fact that after the perception of national parks is changed beforehand, the level of knowledge may also increase.

When preservice teachers' perception and knowledge levels were examined according to their national park visit status, preservice teachers' perceptions who had visited a national park compared to the ones who did not, differed significantly. On the other hand, it is seen that there is no meaningful relationship between the teacher candidates who visit a national park and those who do not, in terms of national park knowledge level. While visiting a national park positively affects preservice teachers' perception levels, it does not affect the knowledge level. In the study conducted by Deniş and Genç (2010), the attitudes of eighth grade students living around national parks towards the national park show a significant difference compared to the fact that they have been to the national park before.

"International Journal of New Approaches in Social Studies - IJONASS" is licensed under a Creative Commons Attribution-NonCommercial-ShareAlike 4.0 International License. 